\title{
RANCANG BANGUN APLIKASI MOBILE LEARNING TENSES BAHASA INGGRIS
}

\author{
Nova Noor Kamala Sari ${ }^{\text {a,1,** }}$, Putu Bagus Adidyana Anugrah Putra ${ }^{b, 2}$, Efrans Christian ${ }^{\mathrm{c}, 3}$ \\ a Jurusan Teknik Informatika, Universitas Palangka Raya, Kampus UPR Tunjung Nyaho Jl. Yos Sudarso \\ b Jurusan Teknik Informatika, Universitas Palangka Raya, Kampus UPR Tunjung Nyaho Jl. Yos Sudarso \\ c Jurusan Teknik Informatika, Universitas Palangka Raya, Kampus UPR Tunjung Nyaho Jl. Yos Sudarso \\ ${ }^{1}$ novanoorks@it.upr.ac.id* ; ${ }^{2}$ putubagus@it.upr.ac.id ; ${ }^{3}$ efranschristian@it.upr.ac.id \\ * corresponding author
}

ARTICLE INFO

Keywords

Tenses

Android

Waterfall

Blackbox

\section{ABSTRACT}

All that requires a media to understand each other and understand one another. The media is language. Language is a medium for communication so cooperation will be created in various aspects. English is the connecting language used as a medium of communication between countries in the world. But some people find it difficult when learning English. The difficulty experienced is due to a lack of understanding of grammar, one of which includes tenses. Learning media as a means of improving the quality of education is very important in the learning process. The research methodology used is waterfall method as an application development methodology. The first step to do is to analyze the needs of the system made, including library research, data collection, consultation, and design. From this analysis a system design using usecase diagrams, activity diagrams and class diagrams is made as a system design to be made. After the system is designed, the next step is to write the program code. At writing the programming language program code used is java, android studio and genymotion as an emulator. Blacbox test results show the software can find out the functions that are not correct, interface errors, performance errors and functionally produce the expected results.

\section{Pendahuluan}

Manusia merupakan makhluk sosial yang tidak bisa hidup sendiri, begitu pula dengan suatu negara. Negara berkembang maupun negara maju membutuhkan partner ataupun suatu hubungan kerja sama dengan yang lainnya dalam menjalankan kehidupannya disegala bidang. Semua itu membutuhkan suatu media untuk saling memahami dan mengerti satu sama lain. Media tersebut adalah bahasa. Bahasa merupakan suatu media untuk berkomunikasi sehingga akan tercipta suatu kerja sama dalam berbagai aspek.

Pada era global sekarang ini kehidupan masyarakat berubah dengan cepat. Dunia semakin menyatu sehingga batas-batas masyarakat dan negara menjadi kabur. Manusia merupakan makhluk yang sempurna. Namun, tidak mungkin seorang manusia mengerti semua bahasa dari setiap negara. Dari gambaran tersebut, terciptalah suatu bahasa penghubung internasional, yaitu bahasa Inggris. Bahasa ingris adalah bahasa jermanik barat yang berasal dari inggris. Bahasa ini merupakan kombinasi antara beberapa bahasa lokal yang dipakai oleh orang-orang norwegia, denmark, saxon dan anglo dari abad ke-6 sampai 10. [1] Bahasa Inggris adalah bahasa penghubung yang digunakan sebagai media komunikasi antar negara didunia. [2] Namun sebagian orang merasa kesulitan ketika mempelajari bahasa Inggris. Kesulitan yang dialami adalah karena kurangnya pemahaman terhadap tatabahasa atau grammar, yang salah satunya mencakup tenses. 
Media pembelajaran sebagai salah satu sarana meningkatkan mutu pendidikan sangat penting dalam proses pembelajaran. [3] Ada beberapa alasan, mengapa media pendidikan dapat mempertinggi prestasi belajar siswa. Alasan berkenaan dengan manfaat media pendidikan adalah pengajaran akan lebih menarik perhatian siswa sehingga dapat menumbuhkan motivasi belajar siswa, bahan pengajaran akan lebih jelas maknanya sehingga dapat lebih dipahami oleh para siswa, dan memungkinkan siswa menguasai tujuan pengajaran lebih baik, metode mengajar akan lebih bervariasi, tidak semata-mata komunikasi verbal melalui penuturan kata-kata oleh guru, sehingga siswa tidak bosan dan guru tidak kehabisan tenaga, apalagi bila guru mengajar untuk setiap jam pelajaran, siswa lebih banyak melakukan kegiatan belajar, sebab tidak hanya mendengarkan uraian guru, tetapi juga aktivitas lain seperti mengamati, melakukan, mendemonstrasikan dan lain-lain.

Android sebagai sistem operasi yang digunakan oleh sebagian besar telepon pintar dijaman sekarang. Selain itu juga, penerapan sistem operasi android dalam perangkat mobile membawa kita pada kenyaataan bahwa sistem operasi ini dapat dengan tepat mampu merealisasikan penyebaran dan kebutuhan asupan akan informasi secara realtime, serta mampu memberikan sebuah sistem informasi yang praktis, ringkas, interaktif dan mudah diakses oleh semua orang ke dalam sebuah perangkat mobile. [4]

Menimbang kemampuan dan kehandalan android dalam menghantarkan sebuah kemampuan komputasi dalam genggaman, membuat penulis tertarik untuk menghadirkan sebuah media pembelajaran interaktif untuk mengenalkan Tenses pada Bahasa Inggris. Tenses mempunyai peranan yang sangat besar dalam suatu kalimat, karena dengan adanya Tenses dapat mengetahui kapan terjadinya suatu peristiwa atau perbuatan. [5] Dalam media pembelajaran yang akan dibuat nantinya akan dikenalkan panduan untuk menguasai Tenses pada bahasa inggris, kuis untuk mengasah kemampuan setelah mendapatkan materi dan dikenalkan juga percakapan-percakapan umum dalam bahasa inggris yang nantinya disertai dengan audio interaktif, sehingga diharapkan dapat membantu pengguna belajar dengan cara yang menyenangkan. Maka berdasarkan pendahuluan tersebut, diangkatlah penelitian ini dengan judul Rancang Bangun Aplikasi Mobile Learning Tenses Bahasa Inggris.

\section{Metodologi Penelitian}

Model yang digunakan merupakan suatu hasil dari siklus hidup pengembangan perangkat lunak Model Waterfall [6] yaitu pada tahap analisis, desain, implementasi dan pengujian. Berikut ini merupakan beberapa tahapan penelitian, yaitu:

1) Studi Pustaka dan Observasi

Metode ini melakukan studi pustaka terhadap buku, jurnal ilmiah nasional dan internasional sebagai pendukung dalam penelitian. Observasi dilakukan untuk mengambil data-data untuk titik dan berapa besar radius yang diperlukan untuk menandakan suatu ruangan yang nantinya akan dijadikan area untuk mengeluarkan informasi.

2) Analisis Sistem

Proses pencarian kebutuhan difokuskan pada software untuk mengetahui sifat dari aplikasi yang akan dibuat, pemodelan proses bisnis menggunakan Data Flow Diagram (DFD) dan Entity Relationship Diagram (ERD). [7]

3) Desain Sistem

Proses ini digunakan untuk membuat blueprint software seperti, perancangan basis data dan perancangan interface.

4) Implementasi 


\section{JURNAL TEKNOLOGI INFORMASI}

[E-ISSN 2656-0321]

[Vol 13. No. 2]

[Agustus 2019]

Proses ini akan dilakukan pembuatan perangkat lunak sesuai dengan perancangan basis data dan antar muka yang telah dilakukan pada tahap sebelumnya.

5) Pengujian Sistem

Proses pengujian akan dilakukan dengan Blackbox Testing yang disertai dengan melakukan simulasi data. Pengujian BlackBox adalah pengujian aspek fundamental sistem tanpa memperhatikan struktur logika internal perangkat lunak [8]. Metode ini digunakan untuk mengetahui apakah perangkat lunak berfungsi dengan benar.

\section{Hasil dan Pembahasan}

2.1 Use Case Diagram

Use case diagram menggambarkan fungsionalitas proses yang di harapkan terjadi dari sebuah sistem. Use case merepresentasikan sebuah interaksi antara aktor dengan sistem.

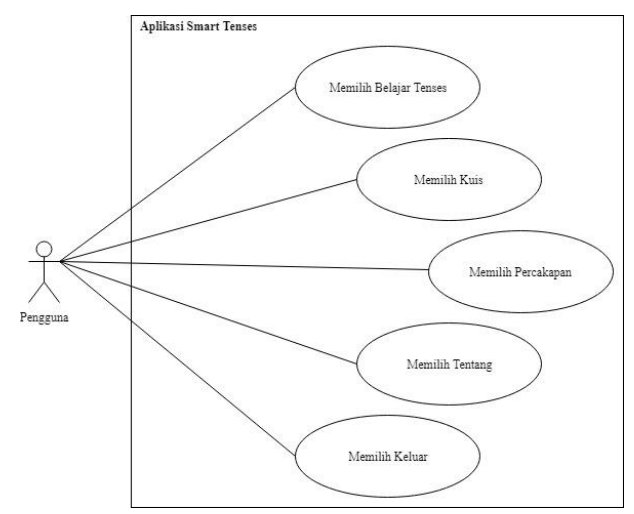

Gambar 1. Use case aplikasi

\subsection{Activity Diagram}

Activity Diagram atau diagram aktivitas berfungsi untuk memodelkan alur kerja (workflow) sebuah proses dan aktivitas dalam suatu proses.

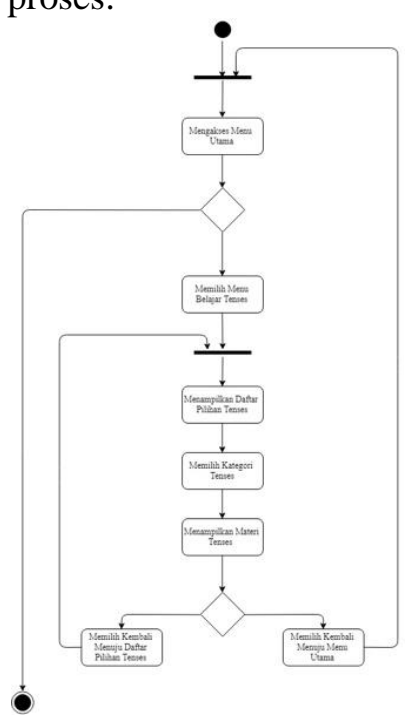

Gambar 2. Activity diagram belajar tenses

Pada diagram yang terdapat pada gambar 2. aktivitas yang dapat dilakukan oleh pengguna apabila memilih menu "Belajar Tenses" adalah Aplikasi akan menampilkan daftar pilihan tenses yang ada untuk dipelajari oleh pengguna, setelah pengguna menentukan dengan memilih materi tenses apa yang akan dipelajari, maka aplikasi akan menampilkan materi tenses yang berisikan rumus 


\section{JURNAL TEKNOLOGI INFORMASI}

[E-ISSN 2656-0321]

[Vol 13. No. 2]

serta informasi berdasarkan kategori tenses yang dipilih oleh pengguna, selanjutnya aktivitas yang dapat dilakukan oleh user terbagi menjadi dua pilihan yaitu : memilih kembali menuju daftar pilihan tenses dan memilih kembali menuju menu utama.

Jika user memilih memilih kembali menuju daftar pilihan tenses, maka Aplikasi akan menampilkan menu daftar pilihan tenses untuk dipilih kembali oleh pengguna. Sedangkan jika pengguna memilih kembali menuju menu utama, maka Aplikasi akan kembali ke menu utama.

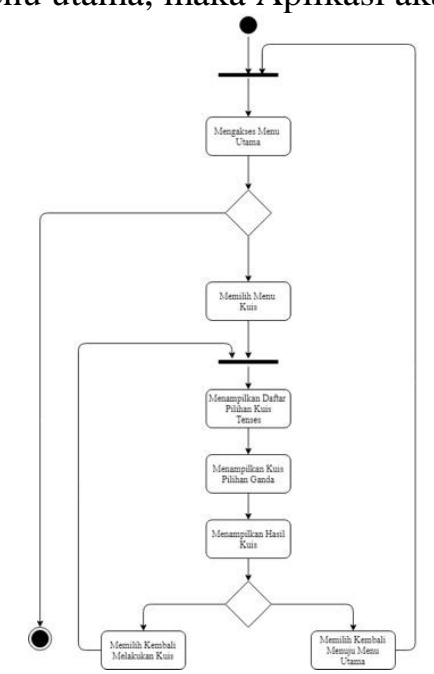

Gambar 3. Activity diagram kuis

Pada diagram yang terdapat pada gambar 3, aktivitas yang dapat dikerjakan oleh pengguna jika memilih menu "Kuis", pada menu Kuis Aplikasi akan menampilkan daftar pilihan kuis tenses yang ada untuk dilatih oleh pengguna, setelah pengguna menentukan dengan memilih materi kuis tenses apa yang akan dilatih, sistem akan menampilkan soal-soal tenses dalam bentuk pilihan ganda dengan materi kuis berdasarkan pilihan user, pilihan jawaban bergantung dari user memilih jawaban mana yang dianggap benar oleh user. Sistem kemudian menampilkan nilai akhir setelah user menyelesaikan soal-soal latihan tenses. Selanjutnya aktivitas yang dapat dilakukan oleh user terbagi menjadi dua pilihan yaitu : memilih kembali melakukan kuis dengan menuju daftar pilihan tenses untuk dilakukan kuis kembali dan memilih kembali menuju menu utama.

Jika user memilih memilih kembali melakukan kuis, maka Aplikasi akan menampilkan kembali daftar pilihan kuis tenses. Sedangkan jika pengguna memilih kembali menuju menu utama, maka Aplikasi akan kembali ke menu utama. 


\section{JURNAL TEKNOLOGI INFORMASI}

[E-ISSN 2656-0321]

[Vol 13. No. 2]

\section{Jurial Keeilmuan dan Aplikasi Bitang Teknik Informatikika}

[Agustus 2019]
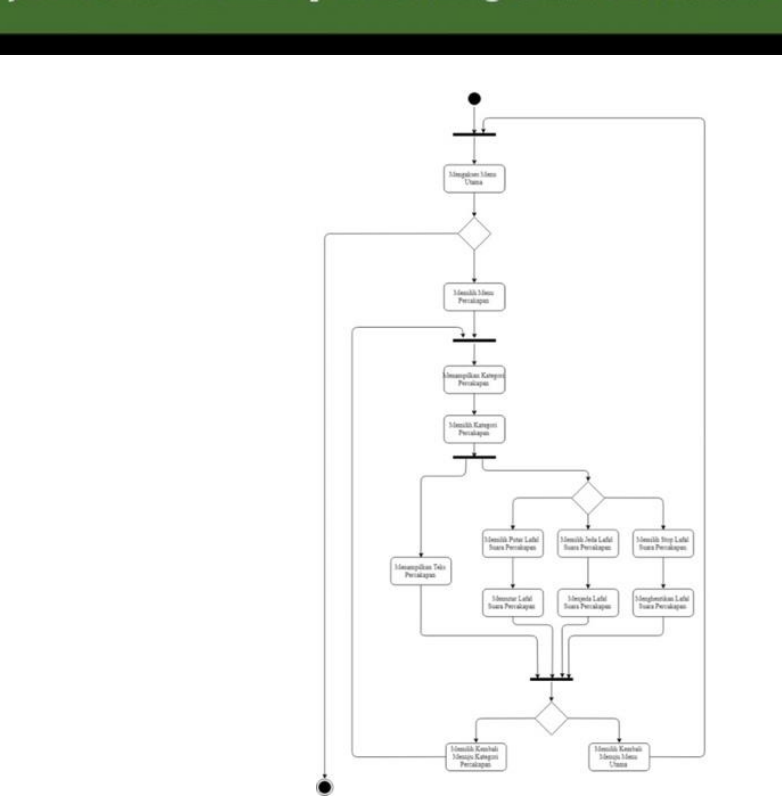

Gambar 4. Activity diagram percakapan

Pada diagram yang terdapat pada gambar 4, aktivitas yang dapat dilakukan oleh pengguna apabila memilih menu "Percakapan" adalah Aplikasi akan menampilkan kategori pilihan percakapan yang ada untuk dipelajari oleh pengguna, setelah pengguna menentukan dengan memilih kategori percakapan apa yang akan dipelajari, maka aplikasi akan menampilkan teks percakapan dan user dapat memilih untuk memainkan, menjeda serta menghentikan lafal suara untuk percakapan berdasarkan kategori percakapan yang dipilih oleh pengguna, selanjutnya aktivitas yang dapat dilakukan oleh user terbagi menjadi dua pilihan yaitu : memilih kembali menuju kategori percakapan dan memilih kembali menuju menu utama.

\subsection{Class Diagram}

Diagram kelas atau class diagram merupakan kumpulan kelas-kelas objek. Sebelum mengetahui dan merancang class diagram dari aplikasi, terlebih dahulu harus mengetahui kelas kelas apa saja yang ada pada sistem yang akan dibuat. Kelas merupakan suatu objek yang memiliki atribut dan method atau dapat diartikan bahwa kelas memiliki informasi yang menggambarkan fitur suatu entitas dan juga penggunaanya. 


\section{JURNAL TEKNOLOGI INFORMASI}

[E-ISSN 2656-0321]

[Vol 13. No. 2]

\section{Jurial Keeilmuan dan Aplikasi Bitang Teknik Informatikika

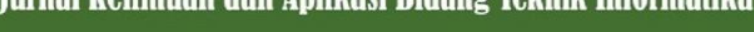

[Agustus 2019]

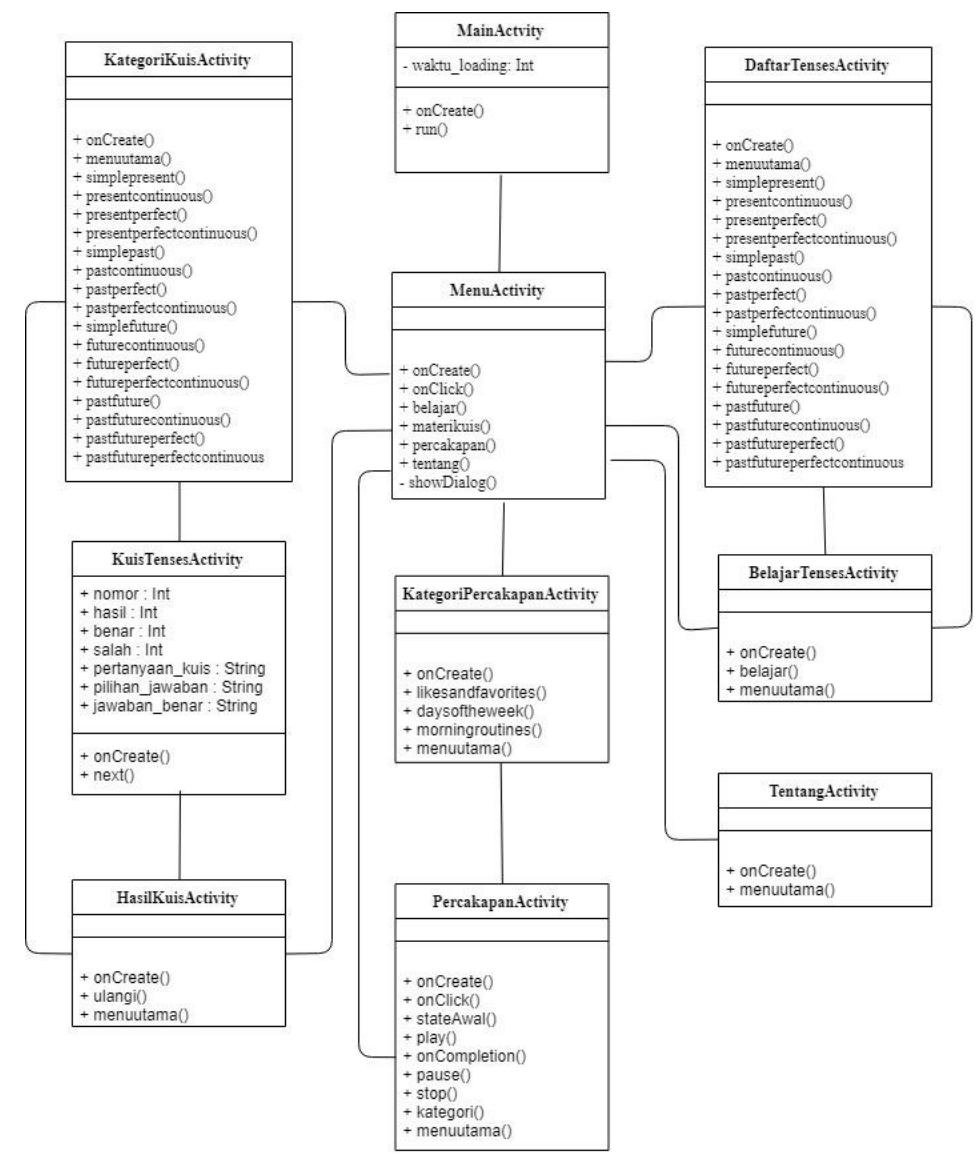

Gambar 5. Class Diagram

\subsection{Scene Menu Utama}

Pada scene menu utama ditampilkan navigasi untuk menu-menu yang ada pada Aplikasi. Berikut pada gambar 6 merupakan tampilan menu utama untuk navigasi ke menu-menu yang ada, menu tersebut diantaranya yaitu Menu Belajar Tenses, Menu Kuis, Menu Percakapan, Menu Tentang dan Menu Keluar.

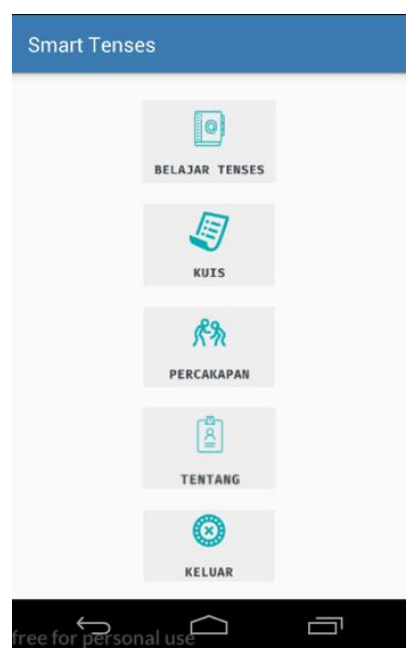

Gambar 6. Menu utama 


\section{JURNAL TEKNOLOGI INFORMASI}

[E-ISSN 2656-0321]

[Vol 13. No. 2]

Jurnal Keeilmutan dann Apilkasi Bitang Teknik Informanikika

2.5 Scene Menu Daftar Tenses

Pada scene Menu Daftar Tenses akan ditampilkan daftar macam-macam tenses yang ada pada bahasa Inggris untuk dipilih oleh pengguna berdasarkan materi tenses yang ingin dipelajari pengguna. Berikut pada gambar 4.3. merupakan tampilan menu Daftar Tenses, terdapat 16 buah button yang merupakan 16 kategori tenses dalam bahasa Inggris.

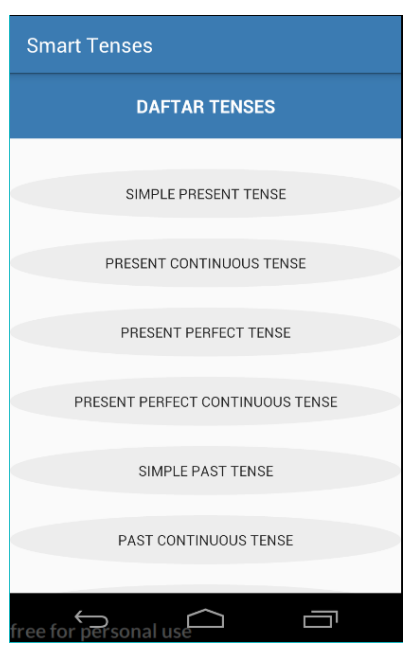

Gambar 7. Menu daftar tenses

\subsection{Scene Belajar Tenses}

Pada scene Belajar Tenses akan ditampilkan informasi mengenai tenses yang dipilih oleh pengguna untuk dipelajari. Informasi yang diberikan berupa definisi serta rumus dan contoh kalimat. Pada scene Belajar Tenses terdapat beberapa interaksi yang dapat dilakukan dalam scene, diantaranya tombol "Menu Utama" untuk kembali menuju menu utama aplikasi dan tombol "Daftar Tenses" untuk kembali memilih daftar tenses lainnya untuk dipelajari. Berikut tampilan untuk Belajar Tenses seperti yang ditunjukkan pada gambar 8 .

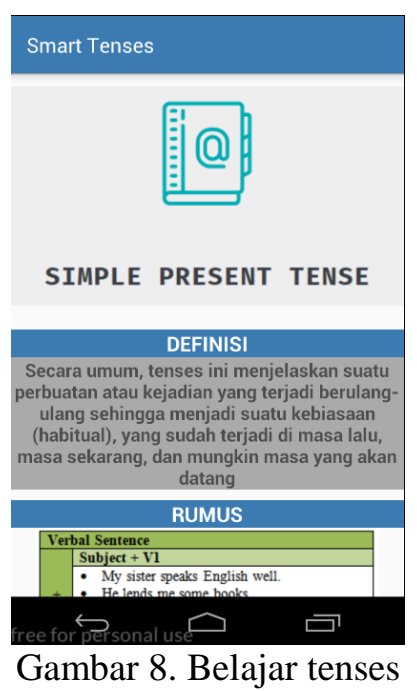

\subsection{Scene Menu Kategori Kuis}

Pada scene Menu Kateogri Kuis akan ditampilkan daftar macam-macam tenses yang ada pada bahasa Inggris untuk dipilih oleh pengguna berdasarkan materi tenses yang ingin dilatih pengguna. Berikut pada gambar 9. merupakan tampilan menu Kategori Kuis Tenses. 


\section{JURNAL TEKNOLOGI INFORMASI}

[E-ISSN 2656-0321]

[Vol 13. No. 2]

\section{Jurnal Keilmuan dan Aplikasi Bidang Teknik Informtailka}

[Agustus 2019]

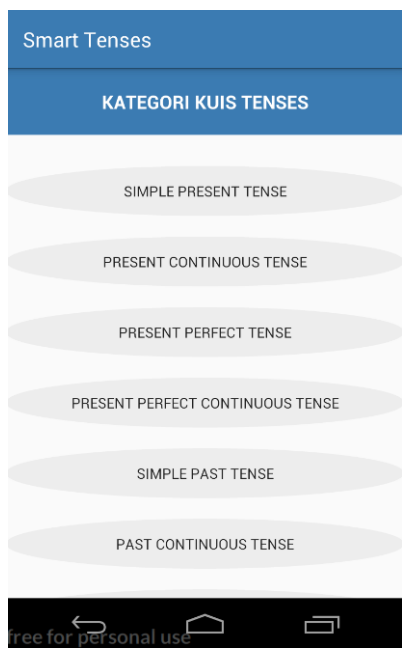

Gambar 9. Menu kategori kuis

\subsection{Scene Kuis Tenses}

Pada scene Kuis Tenses akan ditampilkan soal latihan yang menjadi pertanyaan dalam bentuk pilihan ganda, dimana pengguna memilih salah satu pilihan sebagai jawaban yang dianggap benar dari pertanyaan yang diajukan pada soal, kemudian pengguna menekan tombol next untuk menjawab soal berikutnya. Tampilannya seperti pada gambar 10 .
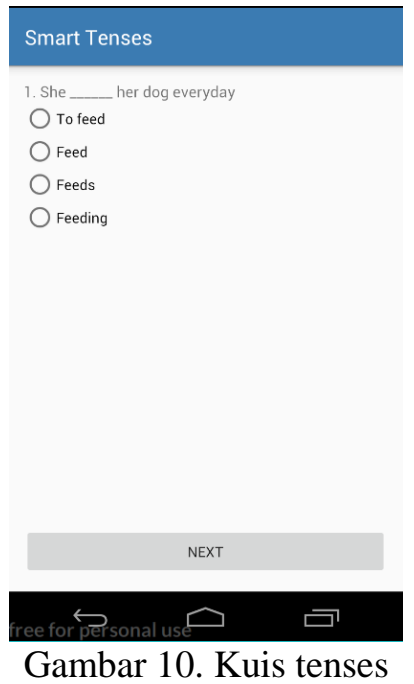

2.9 Scene Hasil Kuis

Pada scene Hasil Kuis merupakan halaman untuk menampilkan nilai atau score setelah pengguna menjawab latihan soal pada menu kuis tenses sebelumnya. Pada menu ini terdapat tombol interaksi "Ulangi Kuis" jika pengguna ingin melakukan kuis kembali dengan kategori tenses yang lain dan tombol "Menu Utama" untuk kembali menuju menu utama aplikasi. Adapun tampilannya seperti yang ditunjukkan pada gambar 11. 


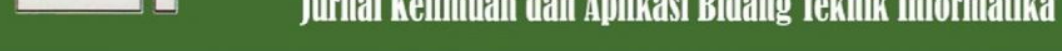

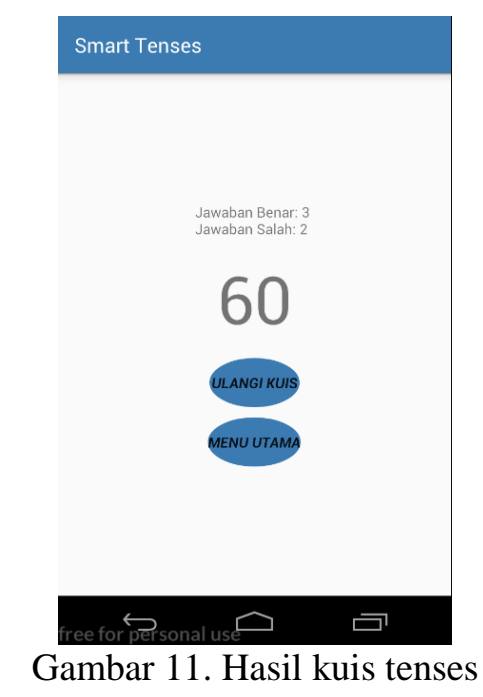

\subsection{Scene Percakapan}

Pada scene Percakapan akan ditampilkan 3 buah tombol untuk play, pause dan stop audio mp3 percakapan serta teks percakapan berdasarkan kategori percakapan yang dipilih oleh pengguna sebelumnya. Pada scene Percakapan terdapat beberapa interaksi yang dapat dilakukan dalam scene, diantaranya tombol "Menu Utama" untuk kembali menuju menu utama aplikasi dan tombol "Kategori Percakapan" untuk kembali memilih kategori percakapan lainnya untuk dipelajari. Adapun tampilannya adalah seperti pada gambar 12 .

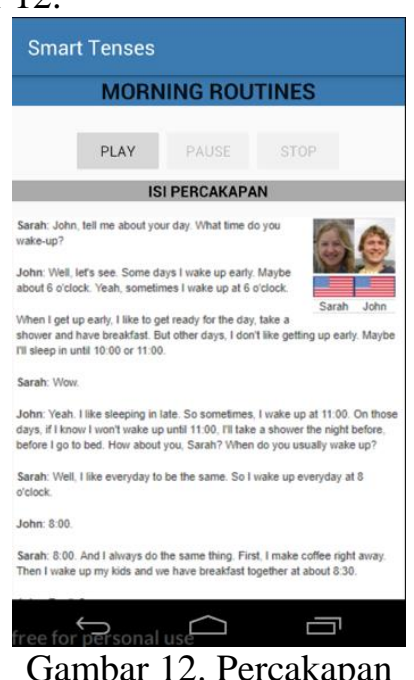

\subsection{Pengujian}

Pengujian yang dilakukan pada aplikasi Smart Tenses menggunakan Blackbox Testing, dimana pada pengujian dengan metode ini hanya memfokuskan kepada fungsionalitas dari aplikasi yang dibuat. 
Tabel 1. Blackbox testing

\begin{tabular}{|c|c|c|c|c|}
\hline No & Kondisi Awal & Hasil yang diinginkan & Hasil Keluaran & Hasil Test \\
\hline 1 & $\begin{array}{l}\text { Tap pada Tombol } \\
\text { Menu Belajar } \\
\text { Tenses }\end{array}$ & $\begin{array}{l}\text { Tampilkan scene Menu Belajar } \\
\text { Tenses berupa } 16 \text { buah daftar } \\
\text { tenses dalam bahasa Inggris. }\end{array}$ & $\begin{array}{l}\text { Menampilkan } \\
\text { scene Menu } \\
\text { Belajar Tenses } \\
\text { berupa } 16 \text { buah } \\
\text { daftar tenses } \\
\text { dalam bahasa } \\
\text { Inggris. }\end{array}$ & $\sqrt{ }$ \\
\hline 2 & $\begin{array}{l}\text { Tap pada Tombol } \\
\text { Menu Kuis }\end{array}$ & $\begin{array}{l}\text { Tampilkan scene Menu Kuis } \\
\text { berupa } 16 \text { buah tombol daftar kuis } \\
\text { tenses dalam bahasa Inggris. }\end{array}$ & $\begin{array}{l}\text { Menampilkan } \\
\text { scene Menu Kuis } \\
\text { berupa } 16 \text { buah } \\
\text { tombol daftar kuis } \\
\text { tenses dalam } \\
\text { bahasa Inggris. }\end{array}$ & $\sqrt{ }$ \\
\hline 3 & $\begin{array}{l}\text { Tap pada Tombol } \\
\text { Present Perfect } \\
\text { Tense }\end{array}$ & $\begin{array}{l}\text { Tampilkan scene Materi Present } \\
\text { Perfect Tenses. }\end{array}$ & $\begin{array}{l}\text { Menampilkan } \\
\text { scene Materi } \\
\text { Present Perfect } \\
\text { Tenses. }\end{array}$ & $\sqrt{ }$ \\
\hline 4 & $\begin{array}{l}\text { Tap pada Tombol } \\
\text { Present Perfect } \\
\text { Continuous Tense }\end{array}$ & $\begin{array}{l}\text { Tampilkan scene Materi Present } \\
\text { Perfect Continuous Tenses. }\end{array}$ & $\begin{array}{l}\text { Menampilkan } \\
\text { scene Materi } \\
\text { Present Perfect } \\
\text { Continuous } \\
\text { Tenses. }\end{array}$ & $\sqrt{ }$ \\
\hline 5 & $\begin{array}{l}\text { Tap pada Tombol } \\
\text { Simple Past Tense }\end{array}$ & $\begin{array}{l}\text { Tampilkan scene Materi Simple } \\
\text { Past Tenses. }\end{array}$ & $\begin{array}{l}\text { Menampilkan } \\
\text { scene Materi } \\
\text { Simple Past } \\
\text { Tenses. }\end{array}$ & $\sqrt{ }$ \\
\hline
\end{tabular}

\section{Kesimpulan}

Metodologi penelitian yang digunakan adalah metode waterfall sebagai metodologi pengembangan aplikasi. Tahap pertama yang dilakukan adalah melakukan analisis kebutuhan dari sistem yang dibuat meliputi studi kepustakaan, pengumpulan data, konsultasi, dan perancangan. Dari analisis tersebut maka dibuatlah rancangan sistem yang menggunakan usecase diagram, activity diagram dan class diagram sebagai desain sistem yang akan dibuat. Setelah dilakukan perancangan sistem maka selanjutnya adalah tahap penulisan kode program. Pada penulisan kode program bahasa pemrograman yang digunakan adalah java, android studio dan genymotion sebagai emulator. Hasil pengujian blacbox menunjukkan perangkat lunak dapat mengetahui fungsi-fungsi yang tidak benar, kesalahan interface, kesalahan kinerja dan secara fungsional mengeluarkan hasil yang diharapkan. Untuk pengembangan kedepannya dapat dikembangkan menu untuk pengguna dapat mempelajari teknik writing.

\section{Daftar Pustaka}

[1] Indah, Angelia. 2012. Pintar Percakapan Bahasa Inggris Super Komplit. Penerbit CV. Aditama. Yogyakarta.

[2] Khatimah R. Yuli \& Asep Gunawan, 2014, Bahasa Inggris When English Rings a bell. ISBN : 978-602282-377-3. Kementerian Pendidikan dan Kebudayaan. Jakarta.

[3] P. B. A. A. Putra, V. H. P. Wijaya, and A. R. Sinana, "Rancang Bangun Media Pembelajaran bagi Murid Sekolah Menengah Pertama Luar Biasa (SMPLB) 1 Palangka Raya," Anterior Jurnal, vol. 18, no. 1, pp. 79-85, Nov. 2018. 
[4] Safaat, H. Nazaruddin. 2012. Pemrograman Aplikasi Mobile Smartphone dan Table PC berbasis Android (Edisi Revisi). Penerbit Informatika Bandung. Bandung.

[5] Andreas Halim.(2012). Kamus 10 Miliyar.Sulita Jaya. Surabaya.

[6] Pressman, S. Roger. 2010. Pendekatan Praktisi Rekayasa. Perangkat Lunak. Edisi 7. Penerbit Andi. Yogyakarta. Halaman 45 -. 46

[7] Rosa.A.S dan M. Shalahuddin. (2013). Rekayasa Perangkat Lunak Terstruktur Dan Berorientasi Objek. Penerbit Informatika. Bandung.

[8] Harsh, B., Khanna, E dan Sudha. 2014. Black Box Testing based on Requirement Analysis and Design Specifications. International Journal of Computer Applications (0975 - 8887). Volume 87-No.18, (February). 